\title{
WPS4596
}

\author{
Policy Research Working Paper 4596
}

\section{Windfall Management for Poverty Reduction: Improving Public Finance Management}

The Case of Chad

\author{
Achille Toto Same
}

The World Bank

Africa Region

Economic Management Department 
Policy Research Working Paper 4596

\begin{abstract}
This paper aims at providing a guide to ensure efficiency in the management of Chad's windfall to support the development process and poverty reduction. The analysis is based on the lessons and experience of countries that have successfully used natural-resource-generated windfalls to launch their development process while avoiding the natural resource curse. The paper also
\end{abstract}

discusses the petroleum management arrangements in place in Chad for poverty reduction. The author argues that the successful management of Chad's windfall for poverty reduction will depend on the effectiveness of oil revenue management arrangements in place in Chad and the government's willingness to improve public finance management (PFM).

This paper-Poverty Reduction and Economic Management Division, Africa Region, Economic Management Department-is part of a larger effort in the department to help African Countries, manage and transform their natural resource wealth into long-term economic growth that spreads the benefits more fairly among their people for an effective poverty reduction. Policy Research Working Papers are also posted on the Web at http://econ.worldbank.org. The author may be contacted at Atotosame@worldbank.org.

The Policy Research Working Paper Series disseminates the findings of work in progress to encourage the exchange of ideas about development issues. An objective of the series is to get the findings out quickly, even if the presentations are less than fully polished. The papers carry the names of the authors and should be cited accordingly. The findings, interpretations, and conclusions expressed in this paper are entirely those of the authors. They do not necessarily represent the views of the International Bank for Reconstruction and Development/World Bank and its affiliated organizations, or those of the Executive Directors of the World Bank or the governments they represent. 


\section{Windfall Management for Poverty Reduction: Improving Public Finance Management}

\section{The Case of Chad}

Achille TOTO SAME 


\section{Table of Content}

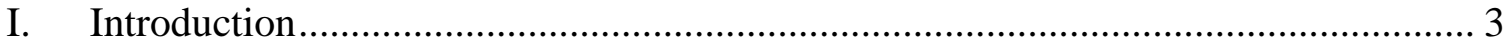

II. Macroeconomic Background and Recent Development...................................... 5

III. Windfall Management and Poverty Reduction.................................................. 11

A. The Challenge of Managing Oil Wealth for Poverty Reduction: Avoiding the Resource Curse

B. Petroleum Management Arrangements in Chad ............................................... 15

IV. The Budget Execution as a Critical Tool for Poverty Reduction ........................ 20

A. Assessing the Overall Expenditure Framework: At the Central and Regional

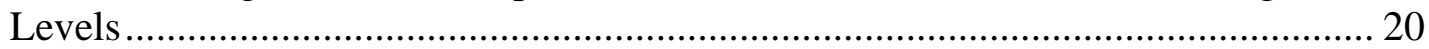

B. Improving the Expenditure Circuit and Management at the Central Level...... 23

C. Improving Expenditure Management at the Regional Level.......................... 25

D. Improving the Cash Flow Management for a Smooth Budget Execution at the Regional Level .......................................................................................... 27

V. Improving the Budget Monitoring and Reporting to Strengthen Accountability ..... 28

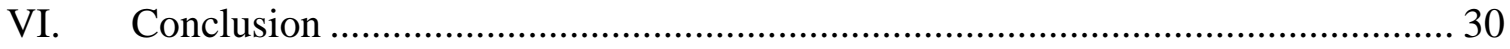

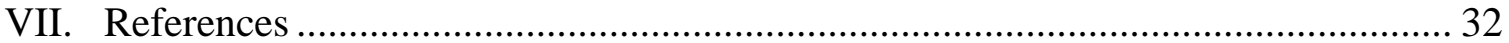




\section{Introduction}

The start-up of oil extraction operations in July 2003 has provided an unprecedented opportunity for intensifying efforts to combat poverty and develop priority public services in Chad. The successful management of Chad's windfall will be critical for its development process and sustained poverty reduction through efficient public finance management (PFM) and particularly, efficient budget execution. Foremost the successful management of Chad's windfall for poverty reduction will depend on the effectiveness of oil revenue management arrangements in place in Chad and the willingness of the government to strictly implement these arrangements.

Windfalls are basically translated or expressed into the budget ${ }^{1}$, and should be integrated into the budget ${ }^{2}$ therefore, the quality of budget execution matters. However, the quality of budget execution depends on the quality of budget preparation. It is possible to execute poorly a well prepared budget, but difficult to execute well a poorly prepared budget. Cash problems encountered during budget execution as it is the case in Chad; are often the result of poor budget preparation (overestimated revenues, failure to identify necessary measures for ensuring adherence to budget authorizations). In this respect, the government of Chad has decided to adopt a number of measures in order to improve the budget preparation. These reforms, which include in particular the improvement of the budget circular, preparation of a Medium Term Expenditure Framework and program budgeting in priority sectors are currently underway.

The budget is the main vehicle and an active instrument in hands of any government to support its development strategy and poverty reduction through efficient allocation of resources to implement the medium-term development vision. It is therefore essential to continue to strengthen the linkage between the Poverty Reduction Strategy (PRS), the sectoral strategies and the program budgets, articulated with the annual budget. Following the preparation of the program budgets 2006-2008, substantive progress were accomplished, but many priority ministries still missing coherent strategies in the medium term. Within the framework of updating the PRSP by end-2007, it will be important to ensure the consistency between poverty reduction priorities and the sectoral strategies of the ministries, and ensure that they are correctly reflected in the program budgets; therefore in the annual budget. In theory, the preparation of the program budgets aims at reinforcing at the same time the effectiveness of the allocation of resources and the operational performance.

In spite of an overall satisfactory performance in terms of growth, the first two years of the oil era were nevertheless characterized by tensions in cash management, accumulation of interior arrears, delays in the budgetary execution in the priority sectors, in particular health and education. These signs are the demonstration of major bottlenecks

\footnotetext{
${ }^{1}$ That justifies why there is a profound need for a sound Public Finance Management (PFM), if windfalls are to be translated into growth and durable poverty reduction; and because in principle, the budget is the very policy instrument through which the government expresses its priorities and policy actions.

${ }^{2}$ The absorptive capacity should then be carefully assessed and adequately dealt with furthermore, excess proceeds from windfalls should be invested in financial assets.
} 
which include inter alia: (i) the prevailing situation of political instability and insecurity which worsened during the period and which supplemented the initial priorities relative to the objectives of improvement of the composition of the public expenditure in favor of the sectors traditionally considered as priority in the effort underway against poverty and to promote the development process; (ii) with the relatively slow progress in the implementation of reforms which were supposed to involve the development of non-oil economy and to promote the private sector through the reform of the public sector and the modernization of the administration in general; (iii) and especially with the persistent weaknesses in the budgetary management and financial control due to the delays noted in the adoption and mostly the implementations of measures to improve transparency in the management of public finance recommended by the Bank.

This paper aims at providing a guide to ensure efficiency in the management of Chad windfall to support the development process and poverty reduction based on the lessons that can be drawn from the experience of the countries that managed to successfully use the natural-resource-generated windfall to launch their development process while avoiding the natural resource curse. The paper presents in Chapter II Chad's macroeconomic background and recent developments. Chapter III discusses the economic theory of natural resource booms, explains the Dutch disease phenomenon and briefly presents some countries that managed to avoid the resource curse. Most importantly this chapter explains the petroleum management arrangements in place in Chad for poverty reduction. Chapter IV discusses the budget execution framework in Chad as a critical tool for poverty reduction; it includes the cash-flow management for a smooth budget execution. Chapter $\mathrm{V}$ explains the necessity to improve the budget monitoring and reporting for increased transparency and accountability, leading to more efficiency and poverty reduction. 


\section{Macroeconomic Background and Recent Development}

Despite the onset of oil and rising revenues since 2004, Chad remains among the poorest countries in SSA. 80 percent of labor force is working in the primary sector and still using rudimentary equipment. The agricultural sector stills the most important source of revenues for the rural poor. After almost thirty years of civil war and relative political stability beginning in the early 1990s, the last two years have seen increased insecurity and political tensions with constant armed attacks from across the Sudanese border in 2005 and 2006 and several coup attempts. However, President Deby won in the election organized on May 3, 2006 and sworn in for the third term on August 8, 2006.

Repeated periods of armed conflict since Chad's independence in 1960, together with weak institutions and a lack of infrastructure have hindered economic development in Chad. Despite some progress in macroeconomic stabilization and reform under Fundsupported programs during the 1990s, Chad's indicators on business climate, governance, and socio-economic conditions remain among the lowest in the world (IMF 2007a). The oil sector accounts for about half of GDP, and has led to high growth rates during 200104; yet, the vast majority of the population still heavily depending on cotton, livestock, and small-scale agriculture for their living. Poverty remains widespread and social indicators are well below the average for Sub-Saharan Africa. Chad is ranked 173 among the 177 countries surveyed in the 2006 UNDP Human Development Report.

The incidence of poverty (defined as the proportion of households with annual spending below what is necessary to meet minimal needs) is estimated at 55 percent according to a 2003 household survey; an estimated four-fifths of the population of about 8.8 million is living on less than a dollar a day ${ }^{3}$. Of the population over 15 years old, more than 73 percent (and 76 percent of women) are illiterate. Access to potable water has improved over past years, but is still limited to one out of three people in 2005. Less than two percent of the population has access to electricity and only 1021 kilometers of roads has been paved on a surface area of over 1.2 million square kilometers.

As already mentioned, Chad has recently become oil producing country; however, the economy remains largely agricultural and pastoral. About 80 percent of the country's population lives in rural areas and continue to make their living $^{4}$ from agriculture and livestock. Cotton is the principal cash crop, employing about 300,000 families. Apart from the petroleum sector, Chad's industry's includes the processing of cotton, meat products, salt, and the production of bottled beer, soap, cigarettes, construction materials, and cereal ${ }^{5}$. The scarcity of human and physical capital reduces labor productivity. The emerging petroleum sector has not had much impact on employment given its capital intensive nature.

\footnotetext{
${ }^{3}$ Line poverty was estimated by the Institut National de la Statistique et des Etudes Economiques et Demographiques (INSEED) and the World Bank team using World Bank methodology

${ }^{4}$ In fact, almost 80 percent of Chad population is located in rural area, without basics infrastructures (lack of potable water supply and adequate health structures) - 80 percent of illiteracy and therefore very poor productivity.

${ }^{5}$ The production of cereals though mostly supports domestic consumption.
} 
Real growth has slowed following the completion of the oil pipeline constructions and a fall in oil production owing to technical problems as mentioned below. In 2005 non-oil GDP rebounded sharply, reflecting more favorable weather conditions for agriculture, subsequent to a drought in 2004 and recovery in cotton. In 2006, real GDP grew about 1.3 percent, reflecting higher non-oil growth offsetting a somewhat larger fall in oil production than envisaged. Real non-oil growth is expected to rise to about 6 percent by 2007, in part reflecting a higher level of government expenditure.

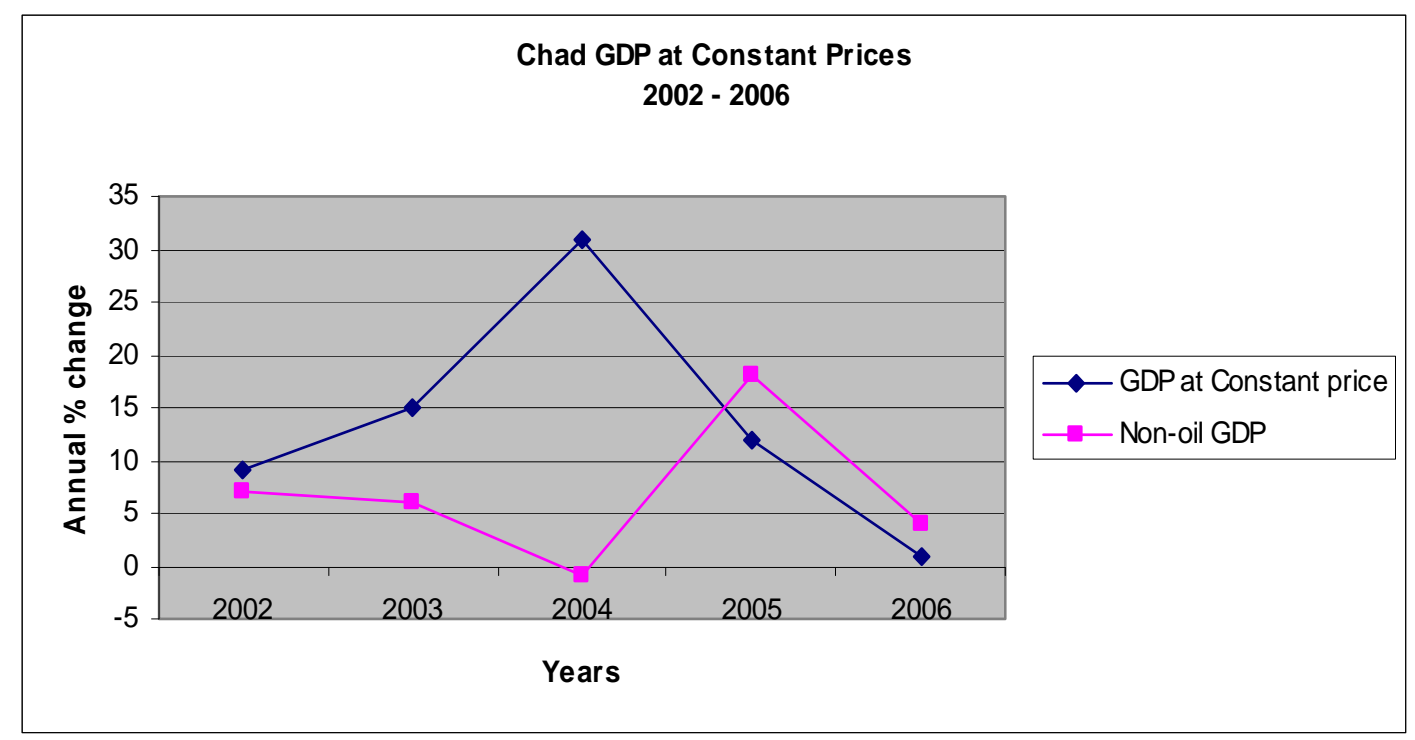

Sources: Chadian authorities Bank and IMF.

Chad' estimations of oil production were to increase steadily from 180,000 barrels per day (bpd) produced in July 2003 to 225,000 bpd by 2004 and remains steady through 2009. In late 2004 oil production reached the 225,000bpd, the maximum capacity of the pipeline, and the annual production totaled 61 million barrels. However, in early 2005, unexpected problems with the porosity of the subsoil led to excessive mixing of water with the oil deposits. The need to separate out the water reduced Doba oil production from 225,000 bpd in December 2004 to around 166,000 bpd in June 2005. Application of reinjection techniques to increase the yield of the Doba fields and the coming on-line of new two oil fields (Nya and Moundouli) helped to maintain oil production at around 173,000 bpd in 2005 and two new satellite fields (Maikeri and Timbre) are coming on stream by 2009 (IMF 2007b). 


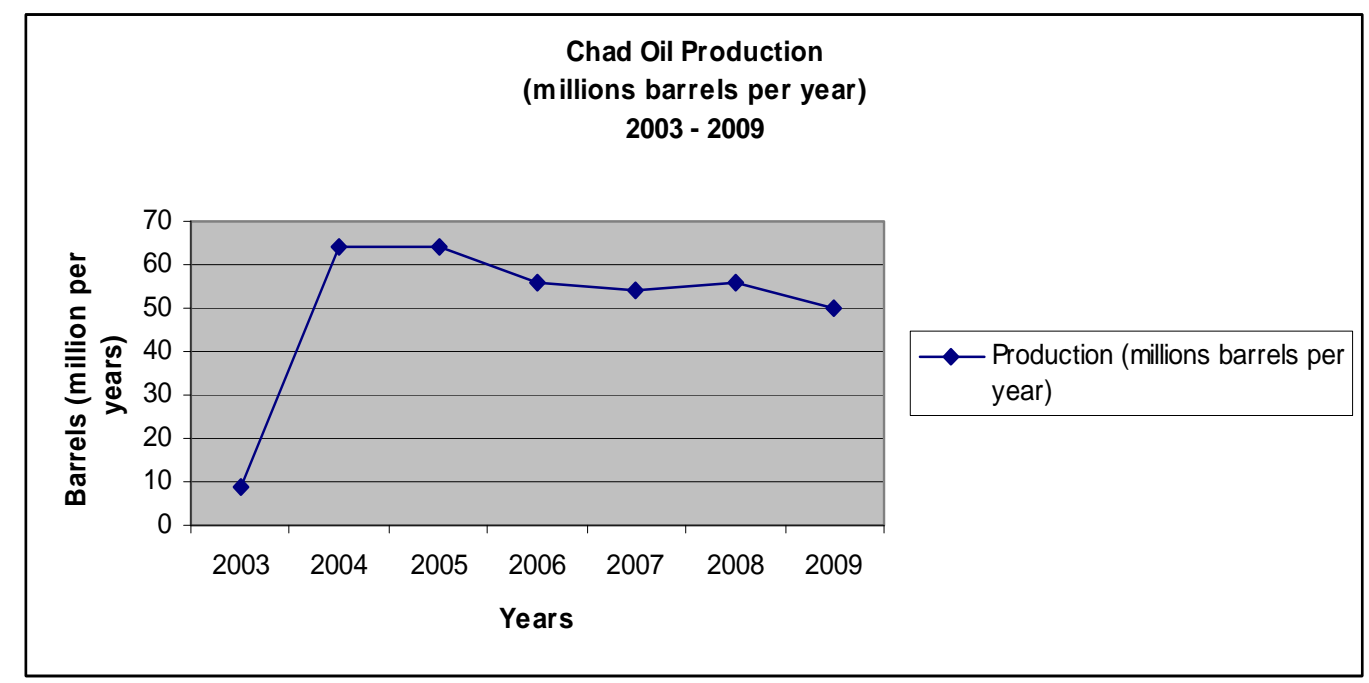

Source: Chadian Authorities and IMF projections.

Inflation increased to an annual average of 8 percent in 2005 owing to a drought in 2004, and, despite a better harvest, remained high in 2006 because of increasing meat prices. The real effective exchange rate appreciated, mainly reflecting the appreciation of the Euro against the U.S. dollar. After stagnating in 2003-04, broad money grew by 32 percent in 2005 owing to a rise in credit to the cotton sector, but monetary expansion slowed down to about 28 percent by late 2006. There is no credible sign of Dutch disease in Chad subsequent to the onset of oil production in addition Chad is a member of CFA franc zone, which had been pegged ${ }^{6}$ to the French franc and, since the beginning of 1999, has been pegged ${ }^{7}$ to the Euro.

The financial health of the banking system appears broadly satisfactory, although vulnerable because of its overexposure to government deposits. Despite the relative soundness of Chad financial system, it remains among the least developed in the region. Commercial bank services are only available in the five largest cities ${ }^{8}$. The microfinance ${ }^{9}$ sector has been gaining importance in recent years. The emergence of microfinance contributed to the improvement in the population's access to financial service. The development of commercial bank network or financial system is critical for the implementation of the poverty reduction strategy since it can contribute to ease transactions and to smooth the budget execution and therefore increases the service delivery for the poorest people in Chad.

Public expenditure increased reflecting the onset of oil revenue, which reached 8 percent of GDP in 2005. Non-oil revenue also bolstered by improved revenue

\footnotetext{
${ }^{6}$ The real exchange rate appreciation in response to an improvement in terms of trade is not affected by the existing exchange rate regime. The essential element of the economy's adjustment relates to the relative price change.

${ }^{7}$ We are not going to discuss the potential advantages or inconvenient of a fixed exchange rate regime.

${ }^{8}$ IMF Country Report No. 06/06/321 - Central African and Monetary Community: Financial System Stability Assessment, including Report on the Observance of Standards and Codes on the following topics: Monetary and Financial Policy Transparency, and Banking Supervision.

${ }^{9}$ The microfinance sector still small though.
} 
administration and growth in the formal sector. It is noteworthy to emphasize that the non-oil revenues were twice the level of oil revenues in 2004 and surpassed again oil revenues in 2005. In 2006, non-oil revenues still substantial compared to direct oilrevenues and are likely to remain more so given the fairly weak projected oil production trend. This implies that the government of Chad should continue its effort to modernize and to reform and promote the agricultural and pastoral sectors together with the rural sector development so as to promote a sustained growth, widen the fiscal space and secure additional revenue from the real sector of the economy and for poverty reduction.

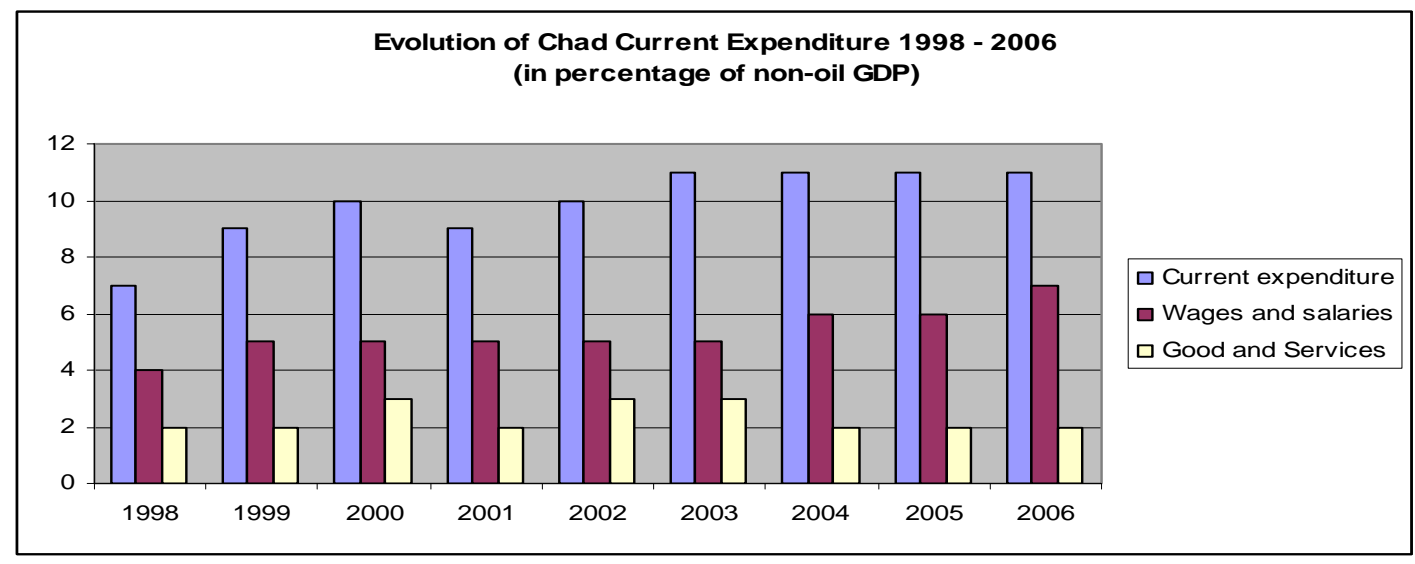

Sources: Chadian authorities; Bank staff estimates and IMF.

Oil $^{10}$ almost doubled government revenue, from 9 percent of non-oil GDP in 2003 to 17 percent in 2005. Primary current expenditure rose from 10 percent of non-oil GDP to 11 percent, and domestically financed investment from 2 percent of non-oil GDP to 4 percent, resulting in an increase of 3 percent of non-oil GDP in the non-oil primary deficit. In 2006, due to the deterioration of the security situation, exceptional military spending are estimated at 4.3 percent of non-oil GDP. However, priority sector expenditure is expected to increase by about 70 percent in nominal terms.

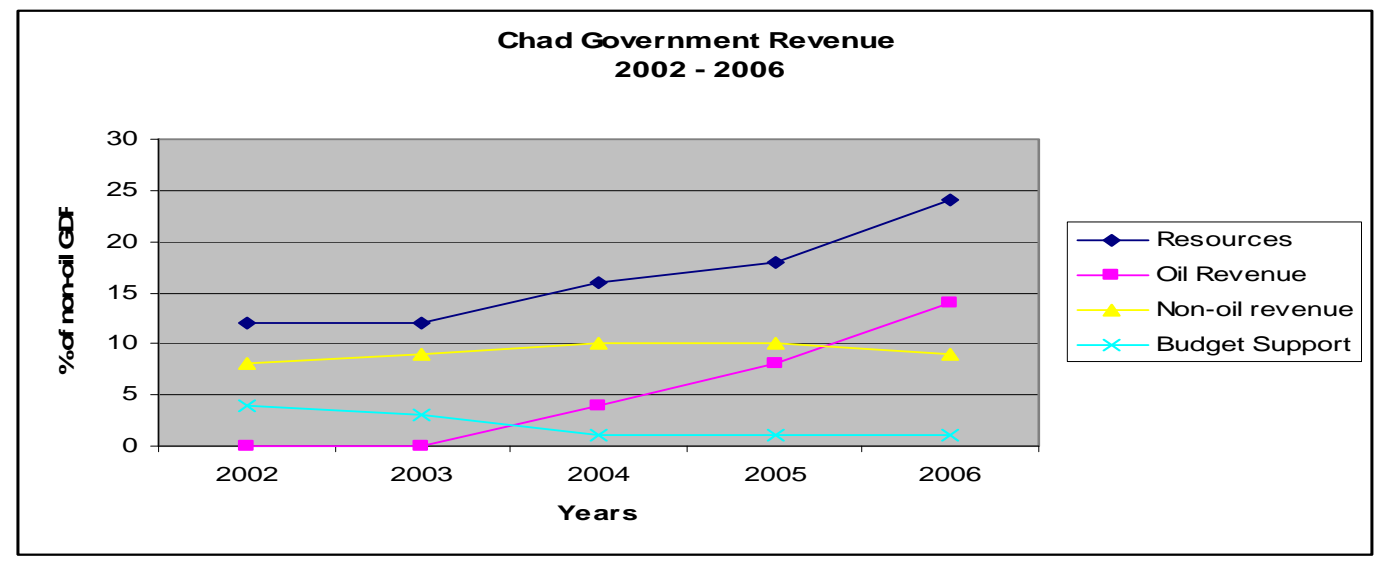

Source: Chadian Authorities and Bank’s staff.

${ }^{10}$ Information on oil revenue is published routinely. The Collège publishes quarterly reports on the execution of oil-financed programs. 
The revenue impact of fall in oil production owing to technical problems in 2005 has been more than offset by oil prices that are about twice as high as were projected ${ }^{11}$. Under the implied well-head price per barrel assumed in early projections and given high initial investments, oil income taxes were not expected until well after 2009. However, in early 2006 oil companies confirmed that the high well-head price which reached US\$33 a barrel in 2005, allowed them to recover part of the upstream investment. As a result, in 2006 oil companies are expected to pay income tax equivalent of about 13 percent of the GDP on 2005 profits, part of which was already paid on March 31, plus equal advance on 2006 income tax, paid in equal quarterly installments.

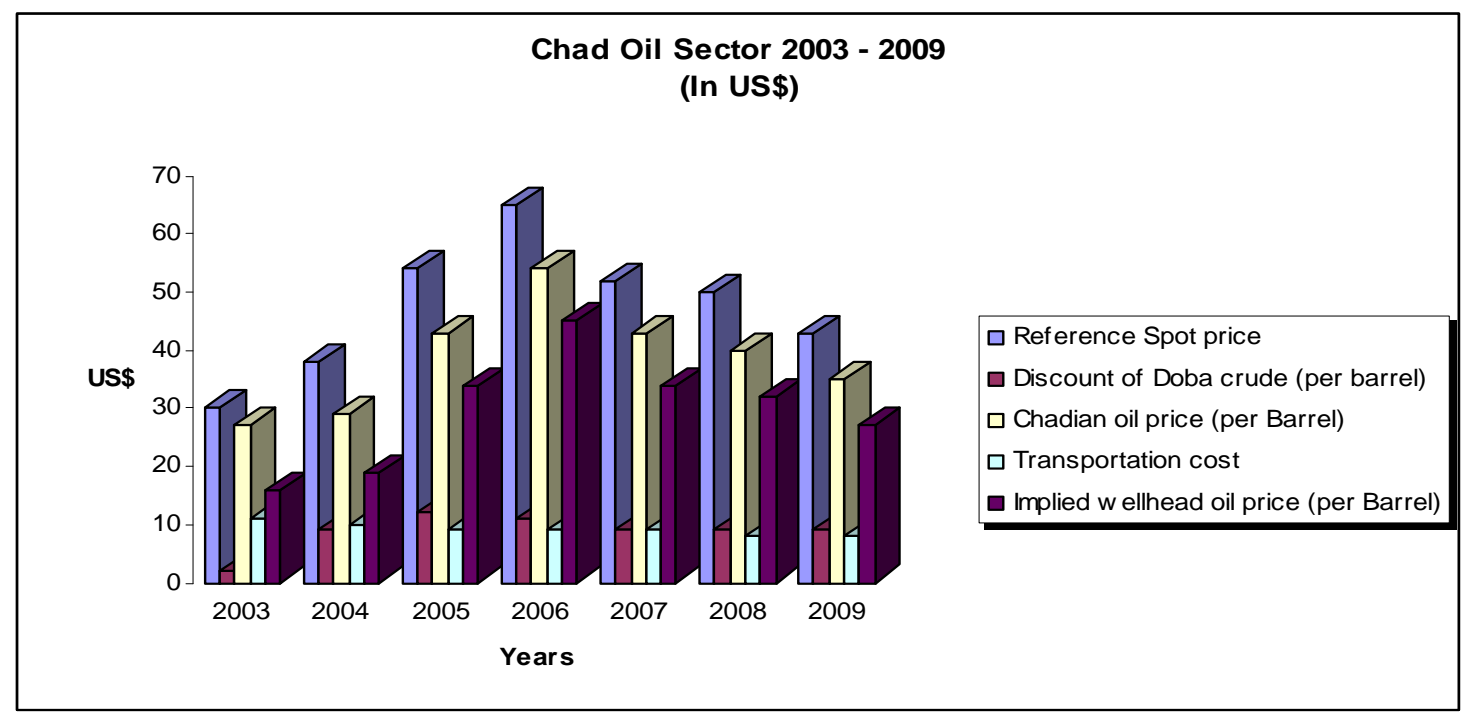

Sources: Chadian authorities Bank’s staff and IMF projections.

Although Chad's basic economic challenge in the next few years is to well manage its oil-rent. However, Cotton and Cattle sectors if well reformed and managed could generate much more revenues per year for rural poor. Therefore, the rural sector development and agriculture and breeding sectors reforms should also be among the highest priorities for Chad development process. Chad's temporary oil windfall should be used to promote the development of the non-oil sector to promote its development process as it has been the case of Malaysia and Indonesia or Botswana therefore ensuring continuation of the implementation of poverty reduction strategy even after Chad's oil is depleted.

\footnotetext{
${ }^{11}$ In late 2005 the discount also narrowed to about US\$9 per barrel compared to early projections, in the expectation of rising demand for heating fuel during the peak-demand in northern hemisphere winter. In early projections, the discount and transportation costs were projected to stay at about US\$10 per barrel over the medium term. In 2004 markets forces pushed the discount up to US\$14 per barrel, as refineries tended to choose light crude over heavy like Chad's oil.
} 


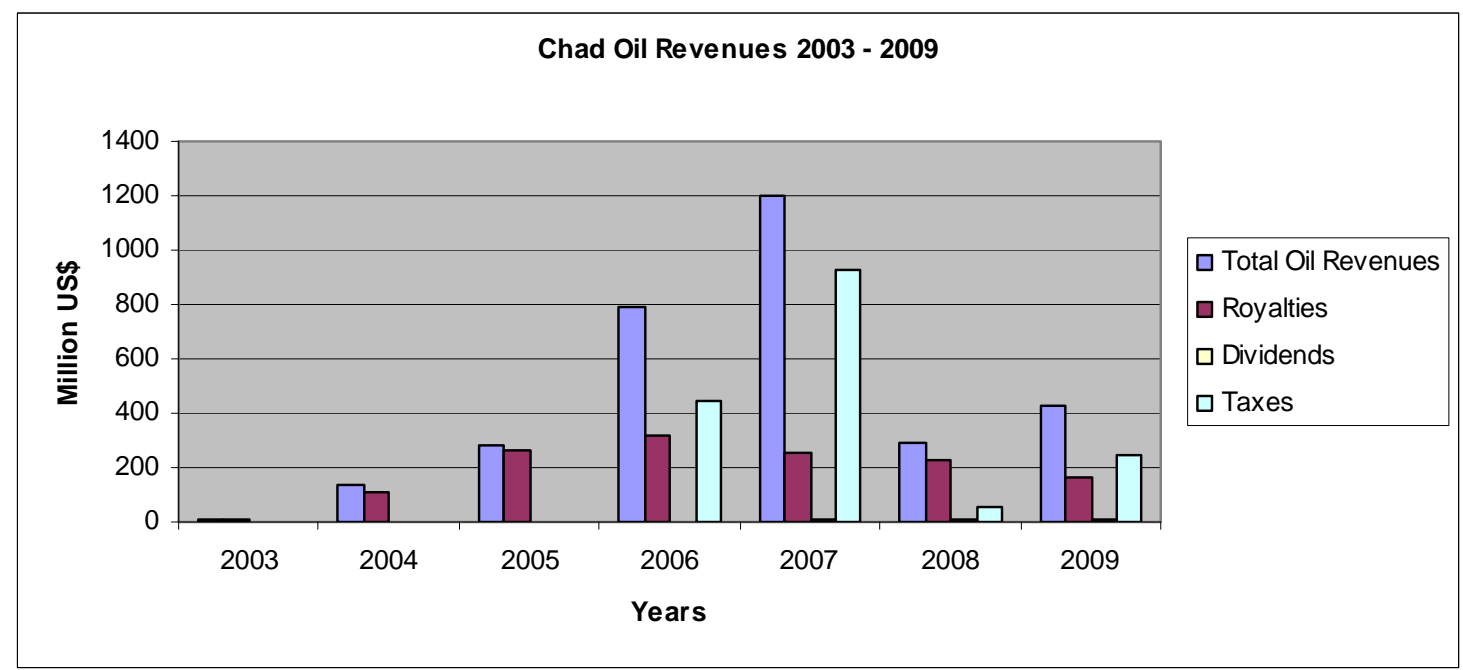

Sources: Chadian authorities and Bank’s staff and IMF.

Despite the rise in revenue, the domestic debt and arrears continued to accumulate. Expenditure control was complicated by poor budget discipline and weak public finance management (PFM), including: (i) failure to observe legal time limits for entering into commitment at the end of the fiscal year, resulting in payment being carried over to subsequent years; (ii) excessive payments outside normal budgetary procedure, and (iii) use of different budget codes by the Budget and Treasury Department, which complicates budget monitoring, and focuses fiscal management on the day-to-day balances in the treasury accounts, without adequate attention to commitment. Furthermore, the 2006 budget became operational only in April 2006. In the meantime, wages were paid nonetheless, and discretionary expenditure focused on clearing 2005 arrears (IMF 2007a).

Chad faces daunting challenges in taking full advantage of the opportunities provided by oil revenue. Indeed, political stability will be essential to allow oil wealth to be used effectively for growth and poverty reduction and to enable the authorities to focus on policy implementation. In that regard it is urgent to strengthen public finance management (PFM) for a transparent, efficient and effective use of public resource so as to develop the non-oil economy for sustained growth and durable poverty reduction. 


\section{Windfall Management and Poverty Reduction}

The materialization of oil revenues constitutes a crucial period, during which, the government should take full advantage to accelerate its structural transformation so as to further strengthen macroeconomic environment including the governance issue. Successful implementation of the reform program regarding public management will result in stricter adherence to the rule of law and more transparent and accountable use of public resources. It will improve the government's efficiency and poverty reduction focus in delivering services in the priority sectors (health, education, basic infrastructure and rural development).

\section{A. The Challenge of Managing Oil Wealth for Poverty Reduction: Avoiding the Resource Curse}

The abundance of natural resources carries a paradox that has inspired innumerable studies of mineral-rich countries in the developing world. Since the 1970s they have consistently underperformed their mineral-poor counterparts on a variety of economic performance, good governance and income equality (Eifert, Gelb and Nils 2002); (Gelb1998); Sachs and Warner 1995, 1997); (Auty 1998, 2001): this phenomenon has come to be known as the resource curse. The "resource curse" is the phenomena whereby a country with an export-driven, natural resources sector, generating large revenues for government, leads paradoxically to economic stagnation and political instability. There is considerable evidence that non-renewable natural resource revenues, especially windfall can, if not properly managed, adversely affect economic growth and poverty reduction.

The resource curse is the result of interaction of two factors. The first is policy mismanagement, often a direct result of the easily available revenues that both lead to rent-seeking behavior and reduced pressures for necessary economic reforms. The second and most prevalent cause attributed to poor rates of economic growth in mineral-rich countries is Dutch Disease. The Dutch Disease phenomenon refers to the loss of competitiveness, or deindustrialization, of a nation's economy that occurs when a natural resource boom raises the value of the domestic currency, making manufactured goods less competitive, increasing imports and decreasing traditional export sector.

The paradox negative impact of a sudden wealth on the economy can be described as follows: an economy experiencing an export boom can be divided into three sectors which are (i) the booming export sector; (ii) the lagging export sector - traditional exports - as the two traded good sectors and (iii) the non-traded goods sector, which essentially supplies domestic resident and might include retails trade, services and construction. In the presence of Dutch Disease, the traditional export sector gets crowded out by the other two sectors (Corden and Neary in 1982). 
Generally the windfalls lead to an appreciation of the real exchange rate by shifting production inputs (capital and labor - resource movement effect ${ }^{12}$-) to the booming mineral sector and non-tradable sector (retail trade, service, and construction), thereby reducing the competitiveness of the non-booming sector mostly agriculture and manufacturing hence participating in their collapse. The shift into non-tradable sector accelerates domestic inflation ${ }^{13}$ (the spending effect of the boom does increase the price of non-traded goods due to increased demand), which is responsible for the real exchange rate appreciation. These short-term macro-adjustment problems result in long-term effects on growth by reducing the country's economic diversity and increasing its reliance on exports from its natural resource sector.

Another well-known issue of resource-rich economies is volatility, known as Boom and Bust cycles, which can equally have negative impact on economic growth. This phenomenon plagues oil exporter ${ }^{14}$ countries, given the importance of oil in the overall economy and government revenues. The economic impact includes unpredictable revenue streams because widely fluctuating export revenues lead to fluctuating levels in overall government revenues (Mikesell 1997). These frequent upward or downward adjustments of fiscal expenditures are costly because they simultaneously discourage private investment and destabilize the government's budget, therefore impeding its ability to sustain investment and social provision and service deliveries (Katz et al. 2004). In addition, once expenditures become entrenched, it is harder for governments to make budget cuts; rather than reversing their spending patterns during busts, they often opt to borrow, and hence, risk incurring huge debt burden.

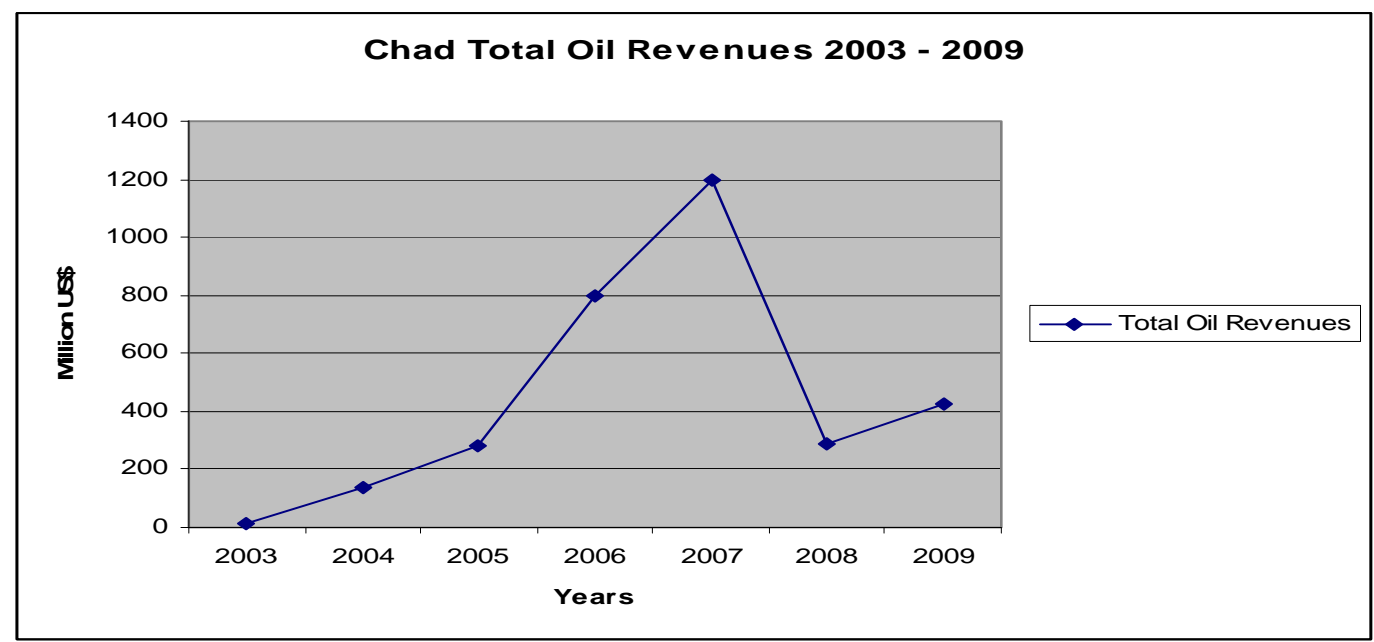

Sources: Chadian authorities and IMF projections.

\footnotetext{
${ }^{12}$ The marginal productivity of labor in the booming industry will increase and attract labor away from the non-booming industry. This change in the sectoral composition of labor is called the resources movement effect of the boom (Corden, 1992). - Managing Oil Wealth: The Case of Azerbaijan. IMF 2004.

${ }^{13}$ As the matter of fact, the non-tradable sector supply is inelastic in the short term so, when demand expands and resources move into the non-tradable sector, this causes prices to increase thereby induces real exchange rate appreciation.

${ }^{14}$ Although market volatility is a problem for all exporters of primary commodities, the phenomena is acute for oil exporting countries given the importance of oil in the overall economy.
} 
The phenomenon of Dutch Disease and Boom and Bust cycles are not the only mechanisms whereby economic growth is negatively affected by windfalls; probably, and almost equally important are the incentives that windfalls create for unproductive investments, rent-seeking and corruption. Many scholars and development practitioners argue that, because windfall rents are concentrated and easily obtained; they exert pressure to engage in rent-seeking, corruption and governments to share increased revenues with the public, often by investing in unproductive public work project or subsidizing food, fuel failing industries and even governments jobs (Auty 1990); Gelb et al 1988) and (McMahon 1997).

The resource curse is not unavoidable though; a sound resource-led development strategy could make a difference; therefore, it is important to understand the dynamic of structural changes that typically occur along with large-scale mineral production. In the context of an oil boom the structure of the economy is fundamentally transformed; these changes, together with the revenues from oil exports, could set the stage for a sustained growth and economic development. Natural resource endowments have helped many countries (Norway, Malaysia, Botswana, Finland and Indonesia) to grow and diversify, in part by providing a basis for developing associated technologies and capital goods industries.

Indonesia has had other export commodities (rubber, coffee, timber) and sought to ensure that they continued to generate considerable income. Indonesian authorities undertook prudent macroeconomic policies, which at time required significant expenditure cuts and correction of misaligned exchange rates in order to adjust to volatility in oil revenue. Indonesia's experience with oil management stands out as relatively successful compared to other oil-exporting countries. The key factors that contributed to this success are as follows: oil was not the only source of export earnings and export of other commodities were generating considerable income; authorities did not rely on oil sector revenues alone and tried to diversify the economy; and the Indonesian government adapted macroeconomic policies to changing external environment.

Malaysia was a traditional commodity (Tin, Rubber and Palm oil and later crude oil) based economy, then; it turned itself into a manufacturer. Malaysia has been able to combine the traditional commodities while building a strong manufacturing sector. Malaysia changed again into services based-economy, although manufacturing still account for more than $30 \%$ of the economy; now is climbing the value-chain ladder trying to move its electronics industry up from commodity "chip making” to testing even designing. In the Meantime, Malaysia will even pay more attention to the traditional commodities that made the country rich. Malaysia's development strategy combined diversification in primary products with diversification into manufacturing.

Botswana's organization of the mineral sector has provided a stable framework for the sustainable exploitation of natural wealth, with important spillover effects on the business climate, and growth linkages. According to Harvey and Lewis (1990) first, the government always emphasized local content and ownership, stressing, the need to be involved in project development and making local inputs a requirement in important 
agreements. Second, sourcing was designed to create further linkages. For example, the decision to manage the infrastructure of cooper-nickel exploration locally led to the initiation of coal production and the creation of Water Utilities Corporation and the Botswana Power Corporation, two entities that later played a major role in advancing particularly urban development. And third, the institutional framework for mining policy involving, the Mineral Policy Committee provided for continuity, expertise, and representation. The government has intervened extensively, mostly through investments in productive infrastructure, to the point that the budget was too heavily weighted to roads, urban infrastructure, railways, airport and telecommunication (Harvey and Lewis 1990). In fact these investments successfully improved living conditions and productivity in the private sphere.

It could be argued $^{15}$ that governments in developing countries, rather than investing the oil revenue proceeds in financial assets, should use them to finance ${ }^{16}$ public expenditure that "crowds-in" private investment and to reduce taxes as far as possible to eliminate distortions and disincentives. This is particularly important in countries where there is an urgent need to build up infrastructure and provide essential services as it is currently the case in Chad. This course of action would support non-oil growth and would create a larger revenue base (widens the fiscal base) in the future.

Government spending contains both an investment and a consumption component; it could ultimately benefit the current generation as well as the future ${ }^{17}$ generation. Taking into account the investment impact on productivity and the incentives it creates for private capital accumulation, countries with low capital stocks such as Chad, benefit most if the government spends the bulk of accruing oil revenues with the aim increasing the return to private investment and raising the country growth rate, Takizawa, Gardner and Ueda (2004). This result does not simply follow from the fact that marginal return on investment spending in Chad would be higher than the return on external financial assets. When the initial capital stock is low and government spending has positive externalities on production, the country would be better off spending more of its oil revenue upfront by increasing both return to private investment and the country's rate of growth. Hence, if oil revenue investment lead to long-term benefits (e.g.; health, education and infrastructure), then spending can permanently raise income, thus minimizing the tradeoff between current and future generation.

An appropriately designed fund or more generally, a natural resource fund can increase transparency and accountability. It should be designed to make it possible to track the utilization of resources, how they are managed, and how much is transferred to the fiscal authority, therefore increasing public scrutiny of public finance and oil revenues management for poverty reduction. Chad is the first country in SSA to have in

\footnotetext{
${ }^{15}$ Lifting the Oil Curse. Improving Petroleum Revenue Management in Sub-Saharan Africa. IMF 2004.

${ }^{16}$ The absorptive capacity should then be carefully assessed and adequately dealt with furthermore, excess proceeds from oil should be invested in financial assets.

${ }^{17}$ Some countries have considered, or turned to the use of savings funds, which seek to create a store of wealth for future generation. This would allow the latter to benefit from part of the revenue arising from the depletion of exhaustible natural resources in the current period.
} 
place detailed petroleum management arrangements (PMA) explicitly designed for poverty reduction. The PMA in place in Chad is analyzed in the next section.

\section{B. Petroleum Management Arrangements in Chad}

The development and operation of the oil fields in Chad, the pipeline and all associated infrastructure in Chad and Cameroon has been an ambitious investment sponsored by a consortium of international oil companies, under Exxon's leadership, and involved: (a) the development of oil fields in the Doba area in Chad, including the drilling of about 300 wells and the construction of associated facilities and infrastructure and (b) the construction of a pipeline of about $1070 \mathrm{~km}$ from the Doba oil fields to Cameroon's Atlantic coast at Kribi. A company was created to manage the project in Cameroon side namely Cameroon Oil Transportation Company (COTCO). The Tchad Oil Transportation Company (TOTCO) was also established in Chad. The overall investment has been about US\$ 4.2 billion $^{18}$ and is currently the single largest private sector investment in Sub-Saharan Africa.

Petroleum revenues present Chad with a unique opportunity to reduce poverty. Drawing on international experience, Chad is aware of the systemic transformation of the economy frequently brought about by the injection of substantial petroleum resources and the need for a longer term perspective for poverty reduction. In that context, the government has worked closely with the Bank to delineate a petroleum revenue management program and has articulated a Strategy for the Management of the Petroleum Economy. The program seeks to reduce poverty by isolating the petroleum revenues and targeting their use to the priority poverty sectors in the context of Chad's overall sectoral programs and global government expenditure patterns.

The thrust of the government's strategy has been to target the bulk of oil revenues for incremental poverty alleviation activities in a transparent manner. A framework guiding the use of oil revenues provides, inter alia, for quantitative targets for the allocation of oil revenues to priority poverty reduction activities, mandatory long-term savings of a portion of the revenues, explicit commitment and disbursement norms, and oversight and monitoring mechanism, including non-governmental mechanisms.

The Revenue Management Program initially agreed with the Bank contains the following detailed elements. Royalties and dividends representing about 85 percent of expected revenues over the first ten years of production will be invested as follows: (a) 10 percent of this revenue stream is to be invested with an external financial institution in long-term investment instruments, and upon liquidation would be used to benefit poverty reduction objectives of future generations ( the Future Generation Fund) ${ }^{19}$ and (b) 90 percent of these revenues will transit through special Treasury account held in one or two private commercial banks in Chad (the Special Petroleum Revenues Accounts) to be used to finance incremental expenditure in the five specified priority sectors relating to poverty

\footnotetext{
${ }^{18}$ Petroleum Development and Pipeline Project - The World Bank and International Finance Cooperation, April 13, 2000.

${ }^{19}$ The Future Generation Fund was to be held with a financial institution acceptable to the bank and the Special Petroleum Revenue Accounts is held in private commercial banks in Chad acceptable to the Bank.
} 
alleviation, distribution to the production region and government recurrent expenditures. It was also agreed that income taxes on the oilfield operations - which were set to begin accruing around the seventh year of production or thereafter, depending in part on oil prices - and on the pipeline company TOTCO will be used to support increased development expenditure generally.

The agreement also includes the operational modalities of the Special Petroleum Revenue Account set as follows: (a) 80 percent of royalties and 85 percent of dividends deposited into the Special Petroleum Revenue Account will be devoted to expenditures in key poverty reduction sectors (education, health and social services, rural development, infrastructure, and environment and water resources); (b) expenditure from oil revenues in these sectors will be incremental to government spending in these sectors prior to the arrival of oil revenues; (c) in addition 5 percent of royalties deposited into such accounts will be allocated as supplement to the oil producing region to be programmed by local authorities; (d) during an initial five-year period (i.e.) before oilfield income taxes provide another possible source of revenues) the residual 15 percent of royalties and dividend can be used to finance general government expenditure in civil sector to help meet pressing government operational needs; after this initial period, this portion will be added to the 80 percent of royalties and 85 percent of dividends used to finance the priority poverty reduction sectors; (e) finally, revenues which cannot be used efficiently for the agreed objectives, or which would jeopardize macroeconomic stability will be sterilized under arrangement acceptable to the Bank.

Under the conventions, the government of Chad is entitled to payments of signature bonus and exploration permits, indirect oil revenue, and direct oil revenue. Signature bonuses and exploration permits which to date have been small, are upfront payments to the host government when a contract is signed for a concession granting exploration rights and the rental of acreage. Indirect oil revenue comprises the corporate income tax levied on TOTCO and three oil companies and the personnel income tax of TOTCO and oil company employees. Direct oil revenue is defined as dividends paid by TOTCO and COTCO, in which Chad is a shareholder, and royalties paid by the consortium at a 12.5 rate. Royalties are calculated on the basis of the average quarterly "implied well-head price" which is equal to the average quarterly Doba sale market price after transportation cost are deducted. The quarterly implied well-headed price is approved by the government at the end of each quarter. 


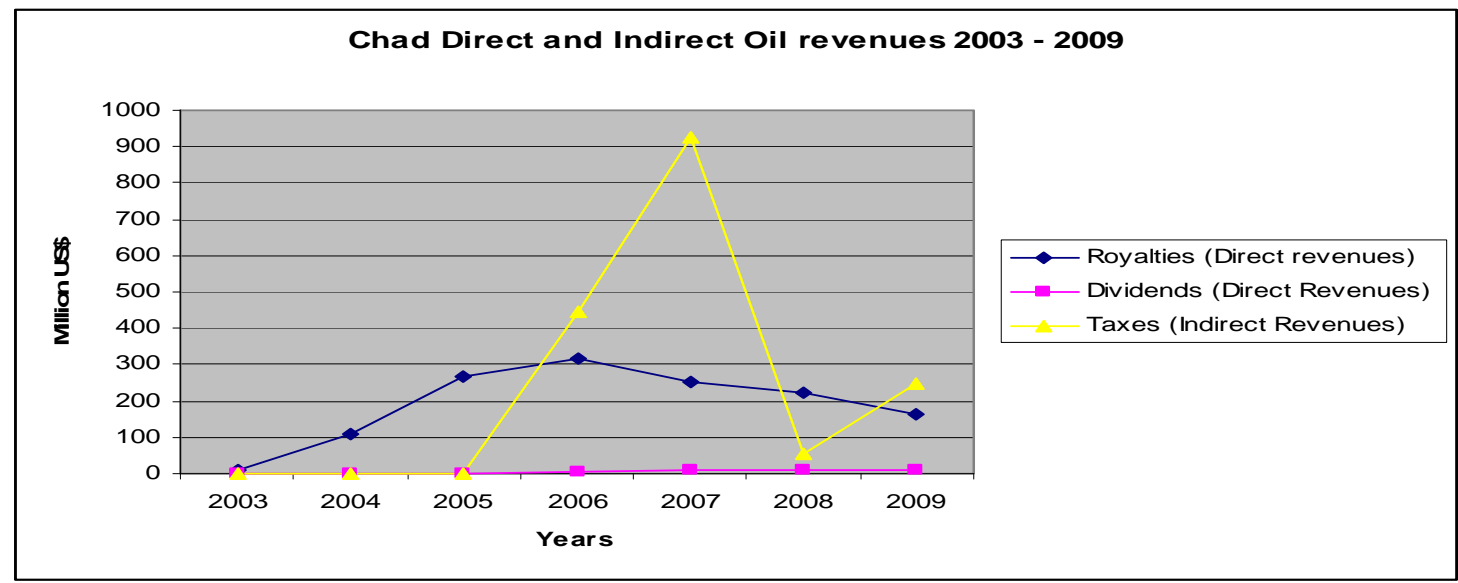

Sources: Chadian authorities; World Bank and IMF.

In order to preserve the integrity of the annual budget and principle of sound budget management; it was agreed and specified in the Petroleum Revenue Management Law $^{20}$ that Fund deposited in special accounts to defray expenditures in priority sectors shall be earmarked in accordance with the public expenditure program prepared annually by the government ${ }^{21}$. The program is understood as a triennial development process and is a reference point for the Finance Act. And the government shall review the program annually. Indeed the principle of Program budgets and MTEF was directed provided by the law, hence consistent with the principles of budget integrity and comprehensiveness as well as with ongoing measures to improve budget management supported by the Bank.

Disbursement modalities were set to: (i) comply with the Finance Law approved by the Parliament; (ii) based on specific expenditure programs for revenues allocated to the priority sectors; and (iii) receive an ex ante visa from an independent institution - The Petroleum Revenue Oversight and Control Committee (CCSRP) or Collège de Controle et de Surveillance des Resources Pétrolières - created by the Act No. 001/PR/99 related to the Oil Revenues Management.

The Collège (CCSRP) mandate is to (a) verify the consistency of special accounts commitments with the Finance Law and (b) authorize and control disbursements from the special accounts, and the allocation of funds. The CCSRP composition is as follows: (i) a Supreme Court judge; (ii) a member of the National Assembly; (iii) a Senator; (iv) the National Director of BEAC; (v) the Director of Treasury; (vi) the Director of Petroleum; (vii) the Director of Planning and Development; (viii) a democratically-designated representative of local NGOs and; (ix) a Trade Union Representative.

The Oversight of oil revenue utilization is also to be exercised by: (i) Parliamentary approval of oil revenue allocation and utilization, through approval and monitoring of the general budget, using information provided by the administration and by the Auditor General's Office and; (ii) the Auditor General's Office in the Supreme Court (Chambre des Comptes de la Cour Suprême) controls the legitimacy of expenditures through (a) the official certification of revenue accounts and; (b) the control

${ }^{20}$ (Law No. 001/PR/99 dated January 11, 1999).

${ }^{21}$ Act No. 001/PR/99 - Oil Revenues Management Law - Section2, Disbursement criteria, Article 12. 
of legal requirements on the allocation of resources between the general budget and decentralized entities, as well as the requirements and rules for the establishment of reserves, and placement abroad of excess resources.

PRML requires monitoring of the mobilization, allocation and utilization of oil revenue through regular audits and reports submitted to the government, and in particular through (i) annual audits of the dedicated special accounts and of the saving account for the future generations; (ii) quarterly statements for the dedicated special accounts; (iii) regular reports on the management of the saving account for future generation, and on the saving accounts where eventual financing surpluses will be placed; (iv) regular reports of the Collège; (v) COBAC audits and reports on the commercial banks managing the special accounts; (vi) annual reports issued by the State Control; and (vii) Auditor General's annual audit of the execution of the general budget.

Confronting mounting financing needs and cash constraints on the ordinary budget, the authorities perceived the original PRML as overly rigid. They also questioned the justification for the Future Generation Fund (FGF) ${ }^{22}$ - the FGF has been abolished given the country's high current needs, arguing that growing balances in the FGF were accompanied by new domestic borrowing. They further noted that the 2003 PRSP identified more priority areas than the PRML, including enhancing security (police and gendarmerie), de-mining, decentralization, and strengthening of the judiciary. Finally, the felt that the arrangement lacked flexibility to counter the impact of declining budget support or to accommodate new priority needs, such as those stemming from the large numbers of refugees, while the earmarking had led to a complex and difficult-to-manage system. According to the IMF difficulties also reflected weakness in PFM and a failure to adhere to established budget execution procedures ${ }^{23}$. In Early 2006, the authorities unilaterally modified the PRML, breaching agreements with the Bank.

Following tense discussions the Bank and Chad's government reached an interim agreement in April 2006. The agreement focused on the use of oil revenue to finance increased priority spending in a revised 2006 budget and on measures to strengthen public finance management and oversight. The Memorandum of Understanding (MOU) reached on July 13, which lifted all contractual remedies and will be in place until the formulation of a new PRML, contains the following main provisions: (a) all oil revenue, not simply oil royalties and dividends, will be considered to finance Chad's poverty reduction strategy; (b) spending will be limited to Chad's absorptive capacity and excess oil revenue saved under a mechanism that will be put in place by the end of 2006; (c) at least 70 percent of total budget resources will be allocated to agreed-upon priority sectors; (d) the list of priority sectors is expanded to include land-mine removal and good governance including justice and anti-corruption; (e) the Collège will be provided additional support and resources; and (f) the 5 percent for development in Doba region will be in effect. The MOU also establishes that the list of priority sectors, as well as the new PRML, will be designed at the time of the PRSP update in late 2007.

\footnotetext{
${ }^{22}$ The growing balances in the FFG were largely offset in 2004 and 2005 by increasing domestic borrowing and arrears.

${ }^{23}$ However, under the PRML implementation period, the share of priority spending in the budget increased and the transparency of oil revenue improved.
} 
The government of Chad has undertaken important reforms and has already accomplished significant progress in the area of budget management and transparency. For that matter the oil management arrangements in place in Chad are by far the most innovative and transparent in Sub-Saharan Africa ${ }^{24}$ and could become an excellent universal model of windfall utilization and management for poverty reduction if consolidated and strengthened. Nevertheless, there are still important challenges ahead. In particular, it will be essential to continue ongoing efforts to improve the budget formulation (Based on the PRSP and its sectoral strategies) and especially the financial programming and the cash flow management upstream for efficient and smooth budget execution and to avoid the disruptive cash shortage downstream during the budget execution. This will substantially improve the effectiveness of service delivery to the poor.

The focus should clearly be given to a sound budget formulation to ensure the efficient execution of the budget. It should be underlined that the provision of additional resources to the priority sectors does barely lead to poverty reduction if programs are poorly prepared and executed. It is important that Chad improves budget execution, to continually improve the quality of public service delivery, and in the context of the broad budget prioritization.

Improving the budget execution for efficient service delivery and poverty reduction in Chad requires restoring the budget credibility by ensuring that resources are available to priority sectors in a predictable and reliable manner, in line with budget appropriations. The budget should be an effective operational instrument to efficiently manage public resources and support the development process and poverty reduction. Finally, the main source of financing the budget will remain the windfall in the medium term; therefore it is critical and fundamental to strengthen the PRML to ensure a continual predictable and transparent flow of resources into the budget for poverty reduction and to safeguard the innovative mechanism in place in Chad.

The interim agreement reached in April 2006 and its subsequent Memorandum of Understanding (MOU) dated July 2006, including all oil revenues (directs and indirects) is a significant progress and should be confirmed in the final agreement. Indeed the initial PRLM only included the direct oil revenues which consist of royalties and bonuses essentially, and dividends paid by TOTCO and COTCO, in which Chad is a shareholder. The indirect revenue, which accounted for 55\% of total oil revenues in 2006 and more than $80 \%$ of oil proceeds in 2007, was not included in the initial PRLM. To give the magnitude and significance of the MOU, by including all oil proceeds; the indirect revenue, income tax in 2007 alone was about US\$938.7 millions almost a billion US dollar and more than CFAF 500 billions that would have been handled outside the PRLM, in a discretionary. The subsequent issue is by which means the resources available in the central government level could be translated into effective poverty reduction on the ground.

\footnotetext{
${ }^{24}$ Poor governance and lack of transparency have been a major concern in oil producing countries in subSaharan Africa. Resource endowment is now often seen as a resource curse; Chad with a well implemented PRML could become a success story and if the PRML is strengthened.
} 


\section{The Budget Execution as a Critical Tool for Poverty Reduction}

In general the budget is the financial mirror of government policy. The preparation process is a powerful tool for coherence. The Budget is both an instrument of economic management and an implicit policy statement, as it sets relative levels of spending and priorities for different programs and activities. In principle, the starting points for expenditure programming are: (i) a realistic assessment of resources likely to be available to the government; and (ii) the establishment of fiscal objectives. The capacity to translate policy priorities into the budget, and then to ensure conformity of actual expenditures with the budget, depends in large part on the soundness of macroeconomic projections and revenue forecasts. Overestimating revenues leads to poor budget formulation and therefore poor budget execution, hence ineffective service delivery. The preparation of a sound macro framework is consequently an essential element in the budget preparation process. In the case of Chad specifically, a sound oil revenues projection is critical to avoid the recurrent internal arrears issue, which undermines the government credibility and hampers the private sector.

Any budget execution system to enable effective service delivery should ideally ensure compliance with budgetary authorization and should have adequate monitoring and reporting capabilities to warrant the identification of budget implementation problems promptly while providing flexibility. Hence, efficient budget execution calls for: (a) ensuring that the budget will be implemented in conformity with authorization granted in the law, both in the financial and policy aspects; (b) adapting the execution of the budget to significant changes in the macroeconomic environment; (c) resolving problems arising during implementation; and (d) managing the purchase and use of resources efficiently and effectively.

\section{A. Assessing the Overall Expenditure Framework: At the Central and Regional Levels}

Reforms designed to rationalize budget execution procedures have been under way since 2001. With technical assistance provided by the International Monetary Fund, the Treasury accounting plan has been revised ${ }^{25}$. To reconcile the budget nomenclature and the accounting nomenclature, redundancies in central commitment oversight were eliminated and a "small" provisional automated system was set up to track commitments and payment orders. Production of a summary table on budget execution (the "fourphase table") was started in 2002. The Ministry of Finance has been setting up an automated expenditure chain management system (Computerized Expenditure Circuit CEC). The government created Directorates of Administrative, Financial and Procurement Affairs (DAAFM) in each ministry, which is in principle responsible for financial management at the ministry level. This should over time further increase the accountability of ministries in budget management.

\footnotetext{
${ }^{25}$ Much remains to be done to reconcile real commitments with payments carried out in the Treasury Department. The revised Treasury accounting is not harmonized with the budget accounting system.
} 
Although these measures have improved the budget management, yet there is a need to rigorously implement an enhanced flow of expenditure and the reliability of financial monitoring. The budget execution remains highly centralized. This high degree of centralization should in theory enable the Ministry of Finance to have access to detailed data on budget execution. However, the existing data are not systematically reviewed, the statements produced by different services are not cross-checked, and information on expenditure execution is not systematically made available to the managers who initiated the expenditures. The central controls are numerous and cumbersome. Various factors explain these difficulties: persistence of complex procedures in the budget execution circuit; lack of clear documentation and/or strict application of the procedures; weaknesses of the technical infrastructure; and inadequacy of human resources.

The budget execution is slow in priority sectors which is attributed to a set of various factors and specifically in delays observed in budget notification and funding delegation. In order to improve budget implementation it is important to accelerate funding delegation at the beginning of the fiscal year. The rules governing the stages of the expenditure circuit are not fully complied with in Chad, which means that commitment often occurs excessively late in the expenditure process, instead of in the beginning. Delays in commitments in priority sectors are partially due to: (i) undue delays in making the budget officially available, especially delegated funding to noncentral levels (which concern priority sectors specifically); and (ii) delays for ministries to prepare and launch procurement processes. Steps are being taken to strengthen newlycreated Administrative and Financial Directorates (DAAFM) to address these issues.

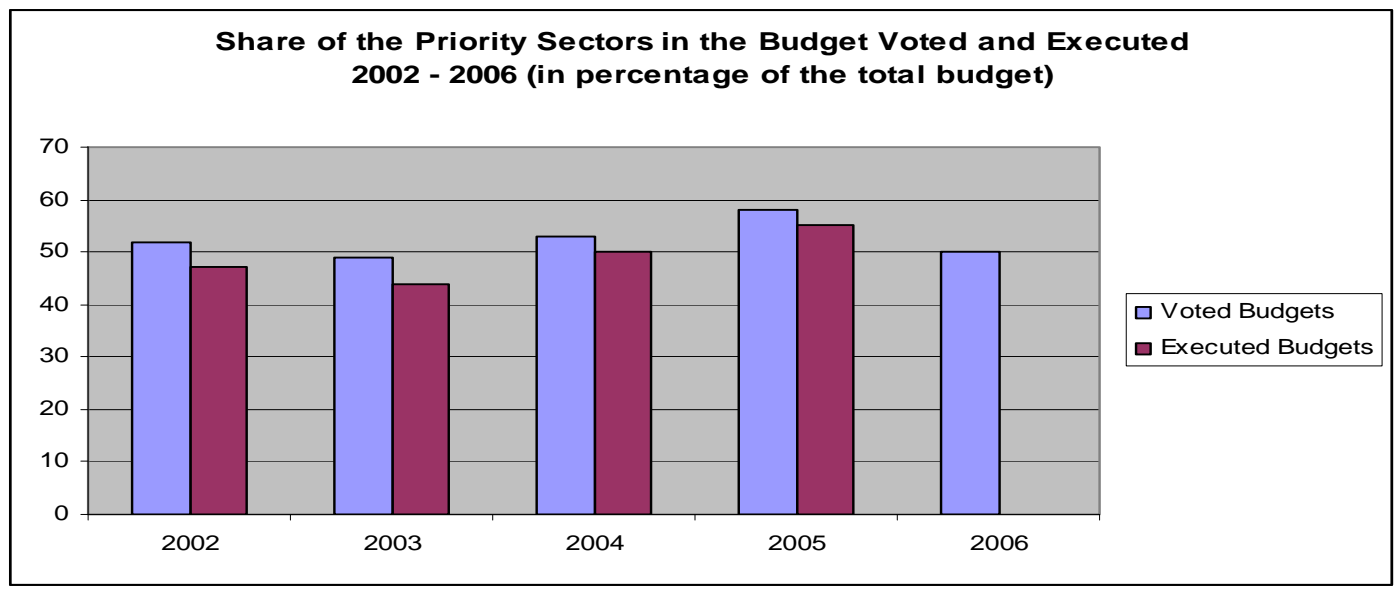

Source: Chadian Authorities and the World Bank.

With the starting of the oil exploitation and the application of the provisions of the law regulating management of the oil revenues, the budget allocated to the priority sectors has substantially increased since 2004. Hence, the share of the budget allocated to priority ministries (including the subsidy in Cotontchad) based on interior resources and budgetary supports, excluding the debt servicing, stabilization account's contribution; reached 52 percent in 2004, more than 57 percent in 2005, but dropped to 49 percent in 2006. It should be added to these amounts, the external assistance related to projects, 
which finances primarily the priority sectors. All in all, the share of the budget allocated to the priority ministries, is generally high. In 2002, the priority sectors represented 74 percent of the capital budget including external resources; this share was about 88 percent in 2005.

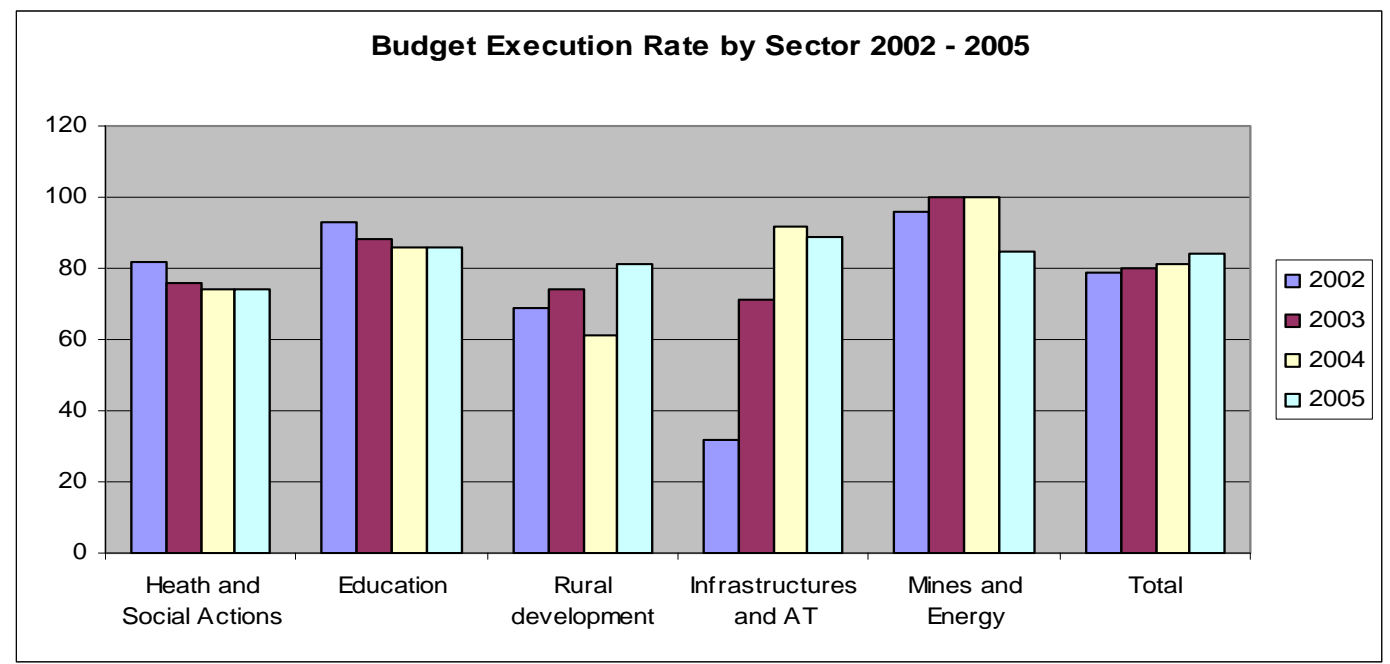

Sources: Chadian authorities and the World Bank

Despite recent progress (simplification of the expenditure circuit, partial computerization), the expenditure circuit remains heavily centralized and cumbersome. Ministries are insufficiently involved in the execution of their budget. This issue is even more severe at the deconcentrated level. There are in Chad, still, significant differences between the voted budget and the budget carried out, and, in particular, inflection of the sectoral priorities in the course of budget implementation. Although it is important to improve the budget preparation and to reinforce the linkages between the PRSP, the sectoral strategies and the program budgets, articulated with the annual budget, it would be necessary also in parallel to: progress toward the implementation of a more unified budget on the basis of an harmonized budgetary classifications and in accordance with the legal provisions governing the management of the oil revenues, of a renovated chart of accounts and an integrated management operating system of public finance so as to enable the tracking of poverty reduction spending.

It is critical to give the greatest priority to protect the budget integrity at the time of the execution phase and to improve for this matter the financial programming; the monitoring of the budget execution during the fiscal year and to lift gradually impediments undermining a smooth budgetary execution, as well with regard to the budget notification, the expenditure circuit (flow of funds) and the procurement process.

Regarding the rules of payment and credit management: Article 19 of Organic Law No. 11/62 of May 11, 1962 states that, notwithstanding the rule on the annualization of appropriations, "appropriations available for capital transactions shall be carried forward by decree of the Ministry of Finance creating an allotment in the same amount over and above the allotments for the following year." This article is not applied. Its application would prevent projects from being blocked because the work schedule, which 
is in any case unpredictable, falls behind. It would avoid the need for extensive recourse to the technique of special accounts ${ }^{26}$ for priority sector expenditures.

\section{B. Improving the Expenditure Circuit and Management at the Central Level}

The system of expenditure cycle in place in Chad includes the usual stages of the budgetary systems inspired by France. Budget accounting covers commitments and orders to pay issued by public officials, while the Treasury records the commitments that it has taken charge of ("pris en charge"), and in principle, of all other operations made by the State. Commitments must first be endorsed through a visa by the financial controller's office, which is in charge of checking their adequacy. Treasury Department controls the payment orders (Ordonnancement) once they are transferred to the Treasury.

Generally the Direction of Payment Orders in the Ministry of Finance authorizes orders to pay. Thus, the Ministry of Finance oversights beforehand every stage of the expenditure process. This high degree of centralization should enable the Ministry of Finance to have detailed data on budget execution. However, existing data are not systematically reviewed, and the statements produced by the various departments are not cross-checked or reconciled. In addition, given that the centralization of the process of budgetary execution is combined with inadequate circulation of information between the Ministry of Finance and the sectoral ministries, credit managers at the ministries do not systematically get the information on the execution of the expenditures that they have initiated.

The circuit of the expenditure of material and investment financed on interior resources, which relates to approximately a third of the budgetary expenditure, constitutes the principal mode of expenditure currently in place in Chad. It is held in two administrative and accounting phases, as described in the Presidential Decree 118-F of June 29, 1963 bearing general payment of the public accounts. The administrative phase relates to engagement (commitment), liquidation (validation) and order to pay "ordonnancement" of the budgetary expenditure; and the accounting phase relates to mainly their payment.

The following administrative structures are involved in the circuit of the expenditure in Chad: (i) Administrators of appropriations, which exert the functions of Directors of the Administrative and Financial Businesses and Material (DAAFM) in the sectoral ministries; they issue the projects of purchase orders (engagement) for their ministry and make carry out the expenditure by the technical directions; (ii) The Management of Financial Control and Commitments Directorate (DCFE) which at the same time engages the budgetary expenditure and controls the committed expenditure (engagement et liquidation); hierarchically attached directly to the Minister of Finance, and not to the Secretariat-general of the MEF likewise the other directions of the

\footnotetext{
${ }^{26}$ Special accounts utilization should be limited because of their lack of transparency nature.
} 
ministry; the DCFE has yet to establish decentralized services in the sectoral ministries and in regions. The Ministerial Decree 248/MEF/CFE/04 of July 5, 2004 envisaged the creation of regional delegations of financial control and engagements; (iii) The Direction de l'Ordonnacement (DO) Directorate of Payment Orders (DPO), a recent structure created in February 2002 and placed under the supervision of the DGB, exerts three functions: it certifies the accuracy of service made, carries out order to pay (ordonnancement) and holds the accounting of order to pay. Also have five regional decentralized services out of nine that exist namely: Under-Centers of Oder to pay Centres de Sous-Ordonnancement (CSO); and finally; (iv) Directorate-General of the Treasury (DGT) which accounts the expenditure for and carries out their payment ${ }^{27}$.

Budgetary expenditure of materials and investment financed on interior resources is carried out in major part by the central services in the capital in Ndjamena. Only a very weak part less than $5 \%$ is carried out in province by the five "Under-Order to Pay Centers"(CSO) to which are addressed authorizations of expenditure delivered by the DCFE and DO in Ndjamena. The public cash shortage makes their payment more random expenditure.

In spite of the clarifications introduced since January 1, 2001, the circuit of expenditure remains long. This defect results partly from the application of the principle of the needed separation of the authority habilitate to issue an order to pay and the accountants enacted in the fundamental financial texts ${ }^{28}$. The complexity and the length of this circuit explain the preference of the suppliers of the government for the derogatory circuits of expenditure (payment by impressed accounts or without preliminary order to pay).

The expenditure circuit was analyzed in the Evaluation of the management of the public finance study ("CFAA") prepared in 2004 with the support of the other Chad partners. As noted by this study, in spite of the clarifications introduced since January 1 , 2001, this circuit of the expenditure remains one of the most centralized French-speaking countries. It does not grant any financial responsibility to the sectoral ministries or directions in charge of the execution of the activities programmed in the budget. The various government services cannot therefore manage in the optimal way under these conditions their share of the budget allocation voted by the "national representation". Thus, it would be desirable to entrust the sectoral ministries in particular by decentralizing the authority to pay (Ordonnancement), to the sectoral minister (or deputy) of his budget.

Payment orders are currently issued by the Directorate of Payment Orders (DPO) or DO in the Ministry of Finance. This authority should be granted or delegated to ministries, whose DAAFM are being progressively strengthened. This would help making the sector ministries more accountable, without eliminating oversight by the

\footnotetext{
${ }^{27}$ République du Tchad - Évaluation de la Gestion des Finances Publiques et des Pratiques Comptables du Secteur Privé. Banque Mondiale - Octobre 2004.

${ }^{28}$ However, the related separation remains essential to safeguard public resources and avoid abusive issuance of orders to pay, if the process was to be carried out by the same person or service.
} 
Ministry of Finance, since it would not affect oversight by the Treasury and by the comptroller's office. It would oblige ministries to improve their accounting and to submit administrative accounts to the Chambre des Comptes. Since it would require the introduction of ledgers and training of managers, this measure should have been introduced gradually as of 2007, starting with the ministries in which the DAAFMs have internal management capacity.

The controller's office theoretically oversees commitments. However, the accounting of commitments (recording of the commitments by the comptroller's office) often comes after the legal commitment (contracts) and even after the delivery of the goods and services to which the legal commitment relates. Thus the monitoring of commitments does not eliminate the risks of over-commitment and arrears, which is in theory one of the purposes of such oversight. In addition, the comptroller's office does not seem to be playing its filtering role correctly.

Multi-year commitments are not recorded. Actually, multi-year commitments concern externally-financed projects. Many multi-year commitments are now financed from internal resources. It will be important to track and monitor these commitments. It is therefore recommended that Article 7 of Organic Law No. 11/62 of May 11, 1962 on budget laws be applied. This article stipulates that multi-year commitments must be authorized by "program authorizations" (also called commitment credits) and that projected payment schedules for these program authorizations must be annexed to the budget. These commitment credits authorize multi-year commitments of capital expenditures but do not give entitlement to payment. For certain compulsory expenditures, such as interest payments on debt or charges for electricity, the commitment and the payment order issuance correspond to the same phase of the expenditure circuit and both take place after validation (liquidation). Streamlining of the circuit for such expenditures could involve either making a lump-sum accounting commitment at the beginning of the year or combining the procedures for commitment and issuance of payment orders.

\section{Improving Expenditure Management at the Regional Level}

Delegation of funding is the deconcentrated method of management used for nonpersonnel operating expenses only. Since 2001, non-personnel payment appropriations allocated to the regional delegations and explicitly delegated in the budget are presented in the budget in specific chapters for the MEN, MSP, the Ministry of Social Action and Family Affairs (MASF) and the Ministry of Public Works and Transport (MTPT). The funding is presented globally for all delegations of the MSP and separately by delegation for the other three ministries. Apart from these four ministries, payment appropriations that could possibly be delegated globally are combined, in the budget, with allotments for the central services. Funding is then delegated at the time of budget execution. The presentation of delegated funding in specific chapters is designed to facilitate budget management at the level of the regional services, by improving the predictability of their budget allotment and enhancing the readability of the budget, by more clearly identifying 
actions linked to the poverty reduction strategy. The process of managing the delegated funding is the following:

- Delegation of funding is undertaken by the DAAFM of the ministry concerned and subject to financial oversight approval in the same way as any other commitment. At present, commitment statements do not distinguish between delegations of funding and other commitments. Commitment of delegated funding is done annually for ministries in the priority sectors and quarterly for the other ministries.

- Once the delegation of funding has been committed and endorsed by the comptroller's office, the managers of the ministries' regional services submit this delegation of funding to the governor or the prefect, who authorizes the service concerned to commit the expenditure.

- The delegation of funding approved by the governor or the prefect is then transmitted to the regional finance directorate for endorsement. In the case of funding delegated to the regional services, the authorization to use the funding is then recorded by the subordinate payment authorization office (CSO). There is no such recording for services situated at the level of the prefectures and subprefectures, because there are any CSOs at that level.

- The spending service enters into a legal commitment and settles the expenditure. The regional delegations transmit the validation file to the CSO, which issues the payment order. This order is then endorsed by the governor and then by the finance delegate, and is then transmitted to the Treasury. In the prefectures and sub-prefectures, payment requests are submitted for the endorsement of the prefect and the finance delegate but, since there are no CSOs, payment orders are issued ex post facto in N’Djamena by the Directorate for Payment Orders.

In theory, there is a total of three checks at the level of the delegation of funding or of the commitment (i) (by the Financial Oversight Directorate, (ii) by the governor or the prefect, and by (iii) the finance delegation-and the CSO) and four checks at the level of the payment order (a) (by the governor or the prefect,(b) by the finance delegationand (c) the CSO - and (d) by the Treasury). These layers of control increase the transaction costs. In addition, in certain cases, intervention by the administrative tutelary body could change the destination initially intended for the expenditure.

The late availability of budget appropriations renders it difficult for the regional services to function. Funding is not delegated and beneficiary services are not notified until June or July. In order to improve budget implementation it is important to accelerate funding delegation at the beginning of the fiscal year. Sometimes, in order to be able to function, the regional services commit expenditure improperly, before being notified of their delegation of funds. Such improper commitments create considerable extra costs, since suppliers that agree to deliver in these conditions will tend to cover their risk by overcharging. The convoluted nature of management of delegated funding is also 
compounded by the problems connected with cash shortages at the treasury level wish implies that there is a need to strengthen the budget preparation and the financial programming upstream.

Expenditure in the regions should be made more predictable and transparent. Therefore, Ministries should at the beginning of the fiscal year prepare a "utilization program" for budget funds by region. This program would indicate by region and by chapter and sub-title, for operating expenditure and "direct investments" based on domestic resources: (i) payment appropriations to be delegated; and (ii) estimates of centralized purchases to be delivered in the region concerned during the fiscal year. This program would be circulated at the beginning of the year to the regional services. It would be monitored during public expenditure reviews.

\section{Improving the Cash Flow Management for a Smooth Budget Execution at the Regional Level}

Good budget management principle requires that governments should ensure both efficient implementation of their budgets and good management of their financial resources. Spending agencies must be provided with the funds needed to implement the budget in a timely manner. Therefore, it is necessary to minimize the interval between the time when cash is received and the time it is available for carrying out expenditure programs.

One of the fundamental flaws characterizing Chad's slow budget execution and poor service delivery is related to its severe cash flow management issue, which manifests itself through recurrent cash shortages combined with an equally poor financial system unable to ensure a secured liquidity and financial transactions as a whole. The development of commercial bank network or financial system is critical for the implementation of the poverty reduction strategy since it can contribute to smooth the budget execution and thus increases the service delivery for the poorest people in Chad.

Indeed a key issue undermining the quality of public services relates to cash flow problems and lack of appropriate transfer of funds in the regions. The payment difficulties in the regions mentioned above are due to inadequate cash balance planning and the lack of a reliable and secure procedure for fund transfers. In these conditions, treasuries situated in regions where revenue is less than payment obligations are not able to make payments and they accumulate arrears, which may be as much as several months' salary for teachers in some places. In addition, when funds are transferred, there are often no special security measures; hence the Treasury agents are at risk.

The Treasury is preparing to upgrade accounting centralization procedures. The procedures for cash flow management throughout the national territory and for fund transfers should be considered in conjunction with the reforms of accounting centralization procedures. Cash flow management and fund transfer procedures must be improved throughout the national territory. For example, each month every accounting unit should prepare a cash flow plan for the following month and project its cash 
requirements (or its cash surpluses). These plans would be centralized by region by the Treasury agency situated in the chief town of the region, which would in turn prepare its cash flow plan and transmit it to the Treasury Directorate-General (DGT) in N'Djamena; the DGT would then organize the fund transfers.

Over the past three years, 12-month cash flow plans have been produced, but until recently, they were not systematically updated and used to manage cash flow resources so as to ensure appropriate implementation of government priorities. In general, when excluding salaries, spending in priority sectors seems also partially conditional on the release of donor-funded budget support and disbursement under projects; in terms of domestic resource management, priority tends to be given to salary payments and payments in non priority sectors.

It is noteworthy to emphasize that Treasury agencies should not have to pay salaries only in cash basis. An alternative system should be considered for example put in place a mandatory payment of salaries through a banking account for all civil servants.

\section{Improving the Budget Monitoring and Reporting to Strengthen Accountability}

A budget reporting system should provide a means of assessing how well the government is doing. Effective reporting is an important instrument for planning and policy formulation. For this purpose, it should provide information on ongoing programs and the main objectives of government departments specifically regarding the budget integrity for example on the use of resources in conformity with legal authorization and mandatory requirements, on operating performance systems and controls.

Increasing the efficiency of budget monitoring is critical to ensure greater transparency and accountability. A comprehensive and timely monitoring of budget transactions could be ensured with adequate information systems recording transactions at each stage of the expenditure cycle, and appropriate electronic connections between the Ministry of Finance and the line Ministries. Basic financial controls can be automated and made when registering the transactions. In order to improve the budget monitoring in Chad, it is critical to improve the budget reporting, which requires appropriate budget accounting procedures.

A well designed Computerized Expenditure Circuit (CEC) could help but only to a certain extent, since invoices can be accumulated upstream and downstream to the computerized expenditure cycle. For example, in a Treasury Information System, if checks are made by the Treasury office, invoices could be accumulated at (i) the level of the spending agency manager, who does not send in the invoices when he knows that the Treasury does not have cash; and (ii) the Treasury level, therefore regardless of the mode of management some principle should be adopted: (a) expenditure should be verified as soon as the goods or services have been acquired; (b) expenditures that are verified 
should be entered immediately into the accounts; and (c) Payment must be recorded as soon as they are made.

Budget implementation should be reviewed periodically to ensure that programs are implemented effectively and to identify any financial or policy derailment. The review of budget execution should cover financial, physical and other performance indicators. Development budgets are often beset by implementation problems because of insufficient implementation capacities and other factors such as delays in mobilizing external financing, overoptimistic implementation schedules or difficulties in importing supplies. It is thus important to have in place mechanisms for reviewing the most significant or problematic projects. These could consist of a regular monthly or quarterly review of projects within the line ministries and a midyear review involving line ministries and central agencies ${ }^{29}$.

The government has taken steps to improve the tracking of budget expenditure until the intended destination, particularly investments spending, for which a tracking survey was entrusted in 2005 with the Ministry of infrastructures. In addition, the ministries took themselves certain internal initiatives, in particular in health and education sectors, but the action plans of these ministries were not updated as envisaged in 2005, and there are neither reliable benchmark, nor quantitative targets as regards improvement of the arrival of the expenditure at intended destination in these sectors. A survey was carried out in the health sector (health centers) with the support of the World Bank in 2005, but has not been yet validated. In the rural development sector, where the first expenditure tracking survey between the decentralized center and services was to be carried out in 2005 on PEFA funds, the survey is yet to be carried out.

It is critical that adequate management measures are gradually put in place to stop the current waste of resources. These measures include, inter alia, the accounting improvement of material, improvement of the inventory and delivery control, and especially a transparent planning of the deliveries, including, the posting of the received deliveries, their comparison with the planned deliveries and their certification by users within each service. It would also be desirable that in each ministry, an action plan is prepared for the implementation of these measures, on the basis of existing ones, and with target indicators as regards improvement of the arrival of the expenditure at intended destination. The social ministries could usefully open the way in this field, on the basis of some projection already carried out. Without a quantitative and qualitative improvement of the arrival of the expenditure at their final recipient, the increase in the budgetary appropriations to the priority sectors will hardly be translated into substantial concrete results on the ground.

\footnotetext{
${ }^{29}$ It is difficult to make accurate forecasts for the implementation of certain programs or developments in economic parameters such as inflation or interest rate. Some immediate needs that were not foreseen during budget execution may appear during budget execution.
} 


\section{Conclusion}

The government of Chad faces daunting challenges in taking full advantage of the opportunities provided by oil revenue. Indeed, security and political stability will be essential to allow oil wealth to be used effectively for poverty reduction and growth and to enable the authorities to focus on policy implementation. It is critical for the government of Chad to accelerate the implementation of PFM modernization reforms underway to increase its efficiency.

Chad has undertaken important reforms and has already accomplished significant progress in the area of budget management and transparency. Indeed, the oil management arrangement in place in Chad is by far the most transparent in Sub-Saharan Africa and could become an excellent universal model of windfall utilization and management for poverty reduction if it is consolidated and strengthened. Nevertheless, there are still important challenges ahead. In particular, it will be essential to continue ongoing efforts to improve the budget formulation ${ }^{30}$ and especially the financial programming and the cash flow management upstream for efficient and smooth budget execution and to avoid the disruptive cash shortage downstream during the budget execution. This will substantially improve effective service delivery to the poor.

The focus should clearly be given to a sound budget formulation to ensure an efficient execution. It should be underlined that the provision of additional resources to the priority sectors hardly leads to poverty reduction if programs are poorly prepared and poorly executed. It is important that Chad improve budget execution, to continually improve the quality of public service delivery and poverty reduction in the context of the broad budget prioritization.

Improving the budget execution for efficient service delivery and poverty reduction in Chad requires restoring budget credibility by ensuring that resource are available to priority sectors in a predictable and reliable manner, in line with budget appropriations. The budget should be an effective operational instrument to efficiently manage public resources to promote the development process and support the poverty reduction effort. Finally, the main source of financing the budget will remain the windfall in the medium term; therefore it is critical and fundamental to strengthen the PRML to ensure a continual predictable and transparent flow of resources into the budget, to develop the non-oil sector or economy for sustained growth and poverty reduction; and to safeguard the innovative mechanism in place in Chad.

The interim agreement reached in April 2006 and its subsequent Memorandum of Understanding (MOU) dated July 2006, including all oil revenues (directs and indirects) is significant progress and should be confirmed in the final agreement. Indeed the initial PRLM only included the direct oil revenues which consist of royalties and bonuses essentially, and dividends paid by TOTCO and COTCO, in which Chad is a shareholder. The indirect revenue, which accounted for 55\% of total oil revenues in 2006 and more

\footnotetext{
${ }^{30}$ Based on the PRSP and its sectoral strategies.
} 
than $80 \%$ of oil proceeds in 2007, was not included in the initial PRLM. To give the magnitude and significance of the MOU, by including all oil proceeds; the indirect revenue, income tax in 2007 alone was about US\$938.7 million, almost a billion US dollars and more than CFAF 500 billion that would have been handled outside the PRLM, in a discretionary way.

Chad's basic economic challenge in the next few years is to well manage its oilrent. However, the cotton and cattle sectors if well reformed and managed could generate even much more revenues per year for the rural poor. Therefore, the rural sector development and agriculture and breeding sector reforms should also be among the highest priorities for Chad's development process. Chad's temporary oil windfall should be used to promote the development of the non-oil sector to promote its development process as has been the case of Malaysia and Indonesia or Botswana therefore ensuring continuation of the implementation of the poverty reduction strategy even after Chad's oil is depleted. 


\section{References}

Acemoglu, Daron, Simon Johnson, and James A. Robinson. 2001a. “An African Success Story: Botswana.” Working Paper 01-37, Department of Economics, Massachusetts Institute of Technology (MIT), Cambridge, MA.

Abidin, Mahani Z. 2001. Competitive Industrialization with Natural Resources Abundance: Malaysia, in Resource Abundance and Economic Development, ed. By R. Auty (Oxford: Oxford University Press), chapter 9.

Auty, Richard M. 1998. Resource abundance and economic development: Improving the performance of resource rich countries. Helsinki: The United Nations University World Institute for Development Economics Research.

------ 2001 Resource abundance and Economic Development. Oxford University Press.

Combating the Resource Curse: An Alternative Solution to Managing Mineral Wealth Erika Weinthal and Pauline Jones Duke University March 2006 Vol. 4.

Chad - Public Expenditure Review - Improving the Quality of Public Services. World Bank, June 2004.

Chad - Public Expenditure Review: Improving Budget Management for Poverty Reduction. World Bank - August 2002.

Gelb Alan et al. 1988 Oil windfalls blessing or curse? New York: Oxford University Press.

Harvey, Charles, and Lewis, S.R. 1990. Policy Choice and Development Performance in Botswana (New York, St .Martins Press).

Haussmann, Ricardo, and Rigobon, R. 2002. An Alternative Interpretation of the Resource Curse: Theory and Policy Implications. Working Paper No 9424 (Cambridge, Massachusetts: National Bureau of Economic Research).

International Monetary Fund - Chad: Article IV Consultation. January 2007.

International Monetary Fund - Chad: Selected Issues and Statistical Appendix. January 2007.

International Monetary Fund, Chad - Staff Report, February 2002.

International Monetary Fund, République du Tchad: Renforcement des administrations financières, Mission report, Décembre 1998.

Katz. Menachem, Bartsch. Ulrich, Malothra. Harinder and Cuc Milan. 2004. Lifting the Oil Curse: Improving Petroleum Revenue Management in sub-Saharan Africa (Washington: International Monetary Fund).

Meeting the Challenge of the Resource Curse - International Experiences in Managing the Risks and Realizing the Opportunities of Non-Renewable Natural Resource Revenues - United Nations Development Programme - January 2006. 
Paul Stevens - Resource Impact - Curse or Blessing? A Literature Survey London: IPIECA - 2003.

Public Sector Governance and Accountability Series. Public Expenditure Analysis, Anwar Shah - The World Bank 2005.

Republic of Chad, Rapport sur l'exécution de la loi de finances, budget 2002, Cour Suprême, Chambre des Comptes, November 2001.

Republic of Chad, Revue des dépenses publiques dans le secteur de l'éducation, Ministry of Education, January 2002.

République du Tchad - Évaluation de la Gestion des Finances Publiques et des Pratiques Comptables du Secteur Privé. Banque Mondiale, Octobre 2004.

Republic of Chad, Revue des dépenses publiques du secteur santé, Ministry of Public Health, October 2001.

Sachs, Jeffrey D; and Warner, Andrew M. (1999) the Big push, Natural Resource Booms and Growth. Journal of Development Economics, Vol59, 43-76.

------ 1995. Natural Resource Abundance and Economic Growth. Working paper 5398 (Cambridge, Massachusetts: National Bureau of Economic Research).

------ 2001. The Curse of Natural Resources, European Economic Review, Vol.45, pp $827-38$.

Schiavo-Compo S. and Tommasi D., Managing Government Expenditure, Asian Development Bank, 1999.

Takizawa. H, Gardner. E, and Ueda. K, 2004. Are Developing Countries Better Off Spending Their Oil Wealth Upfront? IMF Working Paper WP/141(Washington : International Monetary Fund).

Tchad - Revue des Dépenses Publique: Mise à jour. Progrès accomplis et défis à relever en matière de gestion budgétaire. Banque Mondiale, Juin 2006.

Wakeman-Linn. J, Aturupane. C, Danninger. S, Gvenetadze. K, Hobdari. N, and Le Borgne. E, 2004. Managing Oil Wealth: The Case of Azerbaidjan. (Washington: International Monetary Fund).

World Bank, Public Financial Management Capacity Building Project. April 2007.

World Bank Policy Research Working Paper 2899, October 2002 - Benn Eifert, Alan Gelb and Nils Borje Tallroth. - The Political Economy of Fiscal Policy and Economic Management in Oil Exporting Countries.

World Bank, a Chance to Learn: Knowledge and Finance for Education in Sub-Saharan Africa, February 2000.

World Bank, Botswana: An Example of prudent Economic Policy and Growth. Africa Region Findings 2002, p. 161.

World Bank, Public Expenditure Management Handbook, 1998. 
wb241010

F:Isame windfall management.sg1.doc 04/16/2008 10:55:00 AM 